Research Article

\title{
Seismic Behavior of Hybrid Frame Joints between Composite Columns and Steel Beams
}

\author{
Liusheng Chu $\mathbb{D},{ }^{1}$ Qingze Li $\mathbb{D}^{1},{ }^{1}$ Jun Zhao $\mathbb{D}^{2},{ }^{2}$ and Danda Li $\mathbb{D}^{3}$ \\ ${ }^{1}$ School of Civil Engineering, Zhengzhou University, Zhengzhou, Henan, China \\ ${ }^{2}$ School of Mechanics and Safety Engineering, Zhengzhou University, Zhengzhou, Henan, China \\ ${ }^{3}$ School of Natural and Built Environments, University of South Australia, Adelaide, SA, Australia2811
}

Correspondence should be addressed to Jun Zhao; zhaoj@zzu.edu.cn

Received 13 April 2020; Revised 8 May 2020; Accepted 25 November 2020; Published 8 December 2020

Academic Editor: Xiaonong Guo

Copyright (c) 2020 Liusheng Chu et al. This is an open access article distributed under the Creative Commons Attribution License, which permits unrestricted use, distribution, and reproduction in any medium, provided the original work is properly cited.

\begin{abstract}
This study presents experimental and numerical study on cyclic behavior of SRC composite columns-steel beam joints. The pseudostatic experiments were carried out on four samples with different axial loads. X-shaped shear reinforcement was added in the sample no. 4 in order to investigate its effect on the crack resistance in the joint core area. Low-frequency cyclic load was applied at beam ends to simulate the earthquake action. The failure characteristics, hysteretic behavior, stiffness degradation, shear resistance, and displacement ductility were investigated. Experimental results indicated that the failure mode of the joints was mainly shear failure, and the composite joints showed excellent seismic behavior with higher capacity and good ductility and energy dissipation ability. X-shaped shear reinforcement performed well to increase the concrete crack resistance. Shear forces from both experimental test and theoretical analysis were compared, and suggestions were given on modification of theoretical formulas. Simulation using the ABAQUS model showed good results that agreed well with the test results. Steel stress distribution and damage development were analyzed in the model. More parameters of web thickness, stiffener thickness, concrete strength, and stirrups and their influence on shear resistance were studied.
\end{abstract}

\section{Introduction}

SRC composite columns, a typical type of composite columns with structural steel and reinforcing steel bars embedded in reinforced concrete, having both advantageous properties of structure steel and reinforced concrete, have become widely used in high-rise buildings, large-span bridges, and transmission towers [1-4]. External concrete provides protection and restraint to internal steel and hence improves the stability of steel components. On the other hand, the existence of internal steel helps to improve stiffness and strength of column. Overall, SRC composite columns showed enhanced stiffness, stronger energy-absorption capacity, and better ductility than traditional reinforced concrete structures and steel structures. In building structure design, energy-absorption ability is also the basic requirement of its seismic performance [5].
As column-beam joints are critical for overall frame structure's strength and stiffness capacity, column-beam joints failure is the most common and direct reason for structure failure under seismic load. Overall structure's nonlinear seismic performance will be influenced by joints behavior since they are crucial parts in load-transfer and also moment distribution.

How to improve seismic performance and design procedure of column-beam joints has attracted great attention in current research. In these composite columns-steel-beam joints, the property difference between beams and columns has made the analysis more complicated. Some investigations were undertaken, and results were reported by some researchers [6-12]. Chen et al. [6] investigated shear capacity of deep structure steel-concrete beams and proposed analytical models. Cheng et al. [7] reported that load capacity of precast SRC column-beam joints was three times that of 
traditional reinforced concrete joints. Chen et al. [8] proposed Park-Ang modified model for seismic performance evolution, which showed good simulation results in SRC composite joints. Xiang et al. [9] conducted tests on seismic performance on SRC joints with composite columns consisting of T-shaped structural steel section and results showed satisfying shear resistance, ductility, and overall seismic capacity. Chu et al. [10] carried out tests on the cyclic behavior of steel beam-concrete encased steel column joints with three different slab widths. Numerical simulation showed that the slab width and thickness had an important influence on the load-carrying capacity of such joints. Tao et al. [11] carried out tests on four joints specimens and, based on results from load-deflection curves, shear capacity in joint core area, strength, and stiffness degradation and ductility, they reported that seismic capacity can be improved through proper control of design to obtain better failure modes. Seo et al. [12] analyzed influencing factors on effective width of SRC column-beam joints, through comparing design methods of Deierlein, and proposed a modified formula.

In practical design, joints failure or damage is the main reason for overall building collapse or damage, even if the design is following "strong joints and weak elements" rule. Therefore, there is a need to have deep investigation on seismic performance of SRC composite columns-steelbeams joints. In this paper, the pseudostatic experiments were carried out on four specimens. Axial compression load was the main parameter of this research. In addition, based on common crack development mode in core joint area, a new joint type was proposed using $\mathrm{X}$-shaped reinforcing bars in core area and discussions were developed on whether this new joint can delay concrete cracking in the joint area. Then FEM simulation was carried out using ABAQUS model and, through comparison between experimental results and simulation data, suggestions on shear capacity formulas were given.

\section{Experimental Program}

2.1. Specimen. The SRC composite columns-steel-beam joints studied in in this paper followed "weak joints" rule and expected failure mode was shear failure at joint core area. Both structural steel elements in column and beams were in $\mathrm{H}$-shaped sections, which were welded up to form sections. Due to the thin structural steel and other experimental condition limitations, welded joints were adopted for this research. Varying axial pressure ratio was applied to specimens SRC-1, SRC-2, and SRC-3 to investigate its influence on mechanical behavior of composite columns-steel-beam joints. With regard to SRC-4, X-shaped reinforcing bars were applied at core joint area to investigate if they could help to improve anticrack performance of concrete in core joint area; apart from that, all other details of SRC-4 were the same as the other three specimens.

The structural steel used in this paper was Q235 B graded with yield strength of $297 \mathrm{MPa}$ and ultimate strength of $416 \mathrm{MPa}$. Vertical reinforcing bars surrounding structural steel columns were HRB335 graded with yield strength of
$379 \mathrm{MPa}$ and ultimate strength of $534 \mathrm{MPa}$. The stirrup bars in column were HPB300 graded with yield strength of $316 \mathrm{MPa}$ and ultimate strength of $432 \mathrm{MPa}$. C30 concrete was adopted and material properties from concrete test result are listed in Table 1. The geometry details of the specimens were as follows: column height of $1.8 \mathrm{~m}$, beam span of $2.4 \mathrm{~m}$, concrete column cross section size of $240 \mathrm{~mm} \times 240 \mathrm{~mm}$, structural steel column size of $136 \mathrm{~mm} \times 120 \mathrm{~mm} \times 8 \mathrm{~mm} \times 8 \mathrm{~mm}$, and structural steel beam size of $224 \mathrm{~mm} \times 100 \mathrm{~mm} \times 4 \mathrm{~mm} \times 4 \mathrm{~mm}$. Table 2 lists the steel reinforcement details of four specimens and Figure 1 shows the geometry of the specimen and reinforcement/steel details of the joints from four specimens. X-shaped reinforcement bars of specimen SRC-4 were HPB300, which was arranged along the diagonal direction of the joint core area, as shown in Figure 2.

2.2. Loading Schemes and Measurements. Figure 3 shows test setup for specimens. Lateral supporting elements were used on top of column to avoid column instability during loading process. High-strength bolts and supporting beams were adopted at bottom end of column. Axial load was applied on top of columns via hydraulic loading. At two ends of beams, cyclic load was applied through two actuators to simulate the low-frequency cyclic seismic load. The applied load was in the form of combined displacement-control and forcecontrol cyclic loads. The loading scheme followed instructions from JGJ101-96 [13], which is shown in Figure 4.

Prior to yield capacity of $P_{y}$ and when deformation was very small, force-control loading was used and load was applied at increment of $0.2 P_{y}$. After the specimen reached the calculated yield load, loading was applied under displacement-control, using the horizontal displacement of beam ends $\Delta$ at calculated yield capacity as initial displacement for loading. Load was applied at increment of $\Delta$ and repeated three times at each loading level until loading bearing capacity dropped below $85 \%$ of ultimate capacity or when specimen is severely damaged. Downward load was using positive sign. During loading process, the loads at two ends of beam were in opposite directions. The main measurements consisted of applied load, beam end displacement, strain distribution, and deformation of joints. Figure 5 shows strain gauges distribution on column longitudinal and stirrup reinforcements, on beam web and column web in joint core area, and on column flanges and beam flanges.

\section{Test Results and Analysis}

3.1. Failure Modes of SRC-1. Figure 6 shows the crack development at different stage of loading. The first minor crack appeared when loading reached $21 \mathrm{kN}$. Beam flange reached yield strain at load of $35 \mathrm{kN}$ and then beam started yielding which indicated the start of elastic-plastic stage. After the point displacement-controlled load was applied, crack started widening up at the third increment of load. Main cracks formed in the diagonal direction in joint core area. When the load reached the fourth increment and the first cycle, concrete started spalling in the joint core area and the 
TABle 1: Concrete material properties.

\begin{tabular}{lcccc}
\hline Sample ID & $f_{c u}^{k}(\mathrm{MPa})$ & $f_{c k}(\mathrm{MPa})$ & $f_{t k}(\mathrm{MPa})$ & $E_{c}(\mathrm{MPa})$ \\
\hline H1 & 31.1 & 20.8 & 2.1 & 30165 \\
H2 & 31.6 & 21.2 & 2.1 & 30333 \\
H3 & 31.9 & 21.3 & 2.1 & 30419 \\
Average & 31.6 & 21.1 & 2.1 & 30306 \\
\hline
\end{tabular}

TABLE 2: Cross section and steel reinforcement details.

\begin{tabular}{lccccccc}
\hline $\begin{array}{l}\text { Sample } \\
\text { ID }\end{array}$ & $\begin{array}{c}\text { Steel ratio in } \\
\text { section (\%) }\end{array}$ & $\begin{array}{c}\text { Longitudinal bars in } \\
\text { column }\end{array}$ & $\begin{array}{c}\text { Reinforcement } \\
\text { ratio (\%) }\end{array}$ & $\begin{array}{c}\text { Stirrup bars in } \\
\text { column }\end{array}$ & $\begin{array}{c}\text { Stirrup bars } \\
\text { in joint }\end{array}$ & $\begin{array}{c}\text { X-shaped } \\
\text { reinforcing bars }\end{array}$ & $\begin{array}{c}\text { Axial } \\
\text { pressure ratio }\end{array}$ \\
\hline SRC-1 & 5 & $4 \cdot 12$ & 0.83 & $\cdot 8 @ 100$ & $\cdot 8 @ 60$ & N/A & 0.1 \\
SRC-2 & 5 & $4 \cdot 12$ & 0.83 & $\cdot 8 @ 100$ & $\cdot 8 @ 60$ & N/A & 0.4 \\
SRC-3 & 5 & $4 \cdot 12$ & 0.83 & $\cdot 8 @ 100$ & $.8 @ 60$ & N/A & 0.7 \\
SRC-4 & 5 & $4 \cdot 12$ & 0.83 & $\cdot 8 @ 100$ & $\cdot 8 @ 60$ & Yes & 0.4 \\
\hline
\end{tabular}
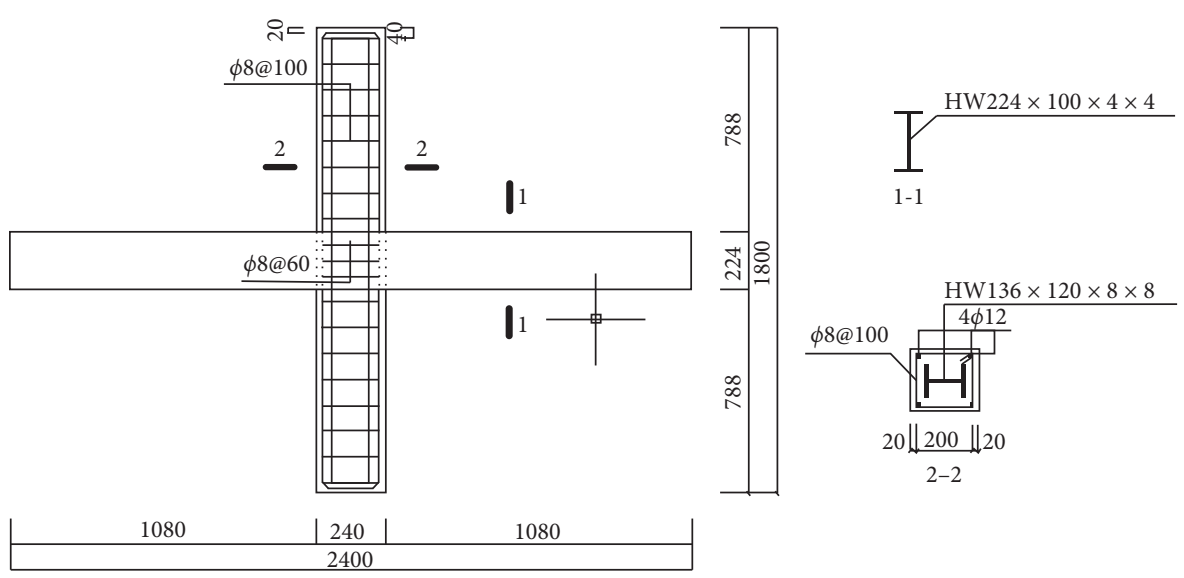

FIGURE 1: Specimen geometry and reinforcement/steel details.

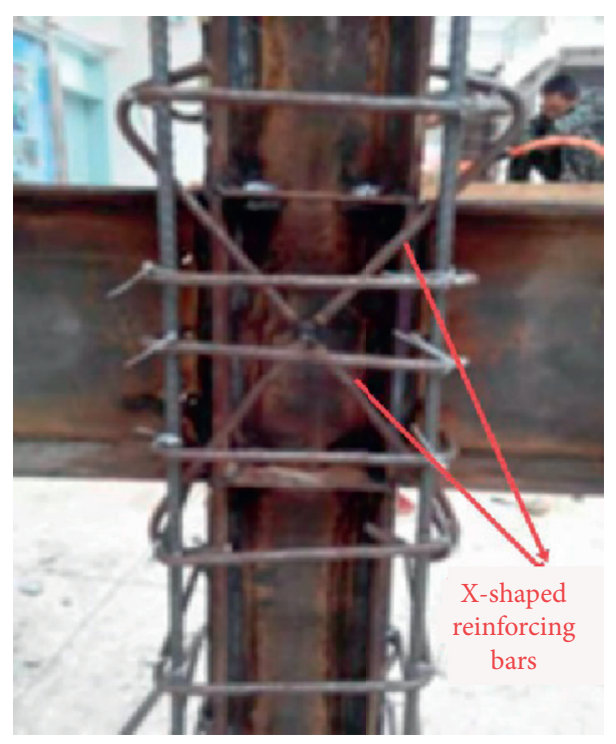

FIgURE 2: Details of X-shaped reinforcing bars and stirrups. 


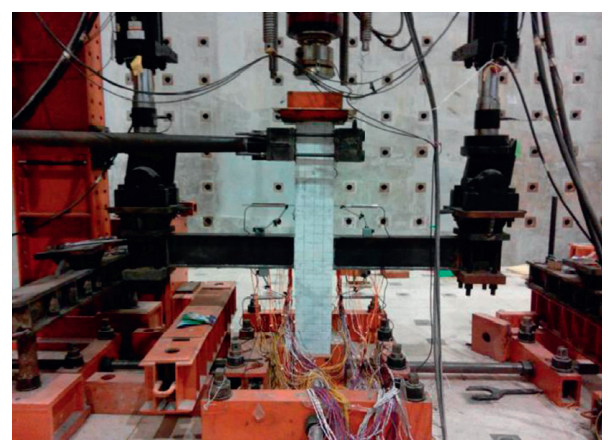

Figure 3: Test setup.

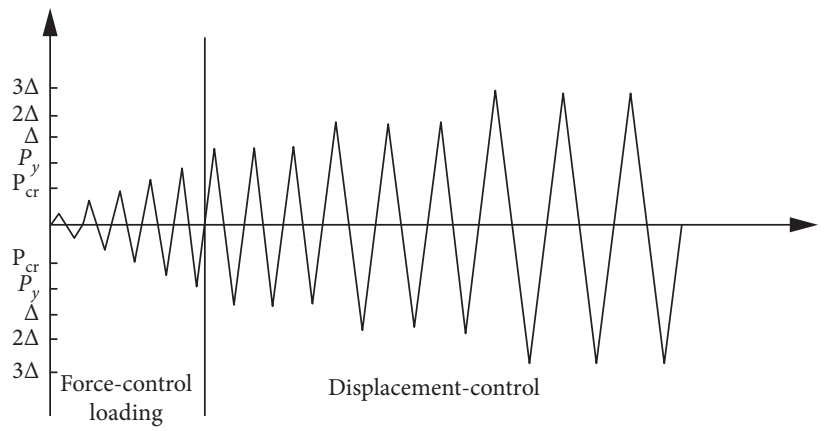

Figure 4: Loading scheme for cyclic tests.

rear bottom flange of the beam on left side of joint started buckling. In the second cycle, linear variable differential transformer (LVDT) dropped. When the load reached the fifth displacement increment and, in the first cycle, the front bottom flange of the beam on left side of joint started buckling, concrete started spalling in big segments and then stirrup was exposed. When load bearing capacity dropped to $85 \%$ of peak value and all cycles in fifth displacement increment finished, the test was stopped.

SRC-2 and SRC-4 showed similar failure modes to that of SRC-1, and buckling also occurred on top flange of beams. Figure 7 shows buckling on beam top flanges in SRC- 4 and final failure mode of the specimen. In specimens SRC-2 and SRC-4, buckling did not appear in beam webs area and shear failure is the main failure mode of concrete in the joint core area.

With regard to SRC-3 joint, when the load reached the third displacement increment, buckling appeared on top flange of beam, which was on right side of joint. When it reached fifth increment of displacement, buckling on top flange of the beam was worsened and severe buckling in beam web area occurred (Figure 8). Due to high axial compression ratio in this specimen, the shear force in beam webs (close to joint area) was quite big; these made the specimen reach yield state very quickly. The main failure modes consisted of buckling at beam ends and shear failure at joint core area. The failure phenomena and failure modes of all specimens are shown in Table 3.
3.2. Hysteretic Curves. Figures 9-12 show hysteretic curves and envelope curves for four specimens at loading point on right-hand side of joint. All four specimens showed full hysteretic curves, which indicates good energy dissipation ability of these composite column-steel-beam joints. SRC-3 showed most full hysteretic curves, which indicates that, with higher axial compression ratio, structural steel's strong mechanical properties could be used to most potential and hence improved specimens' plastic deformation ability. The shapes of envelope curves and hysteretic curves were very close for both SRC-2 and SRC-4, which indicates that introducing X-shaped reinforcing bars can only improve crack resistance of concrete but has no impact on other mechanical performances of joints.

3.3. Envelope Curves. From Figures 9-12, it can be seen that envelope curve is in S-shape, which indicates that during loading all specimens underwent four stages: elastic stage-plastic stage-ultimate loading-final failure. Table 4 lists characteristic loading of four specimens. Combining with Figure 13 , it shows positive displacement, SRC-3 showed slower increase on envelope curve compared to SRC-1 and SRC-2, while after reaching ultimate capacity, the envelope curves for SRC-1, SRC-2, and SRC-3 were very close and all see a flatter descending curve. For negative displacement, SRC-3 showed faster increase on 


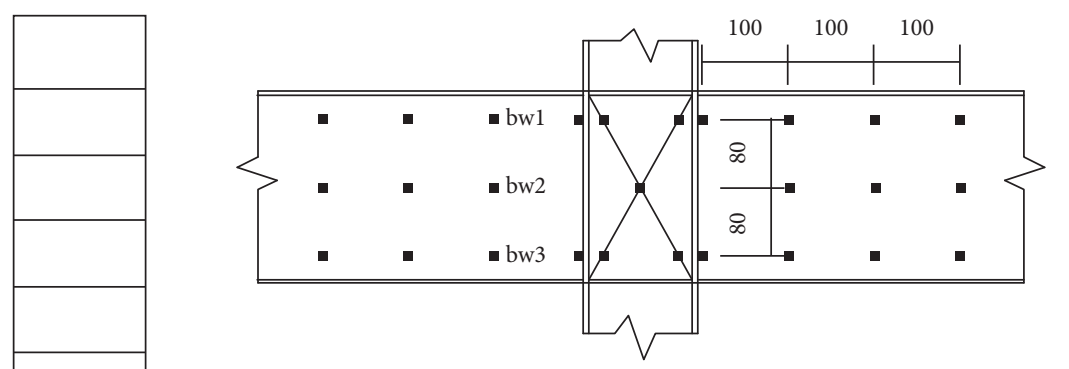

(b)

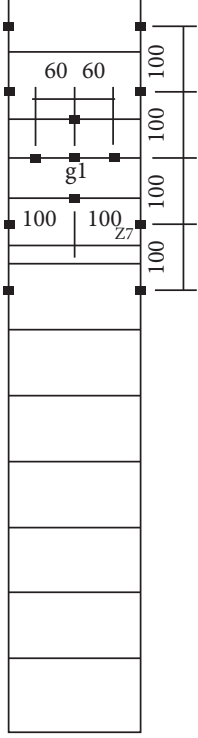

(a)

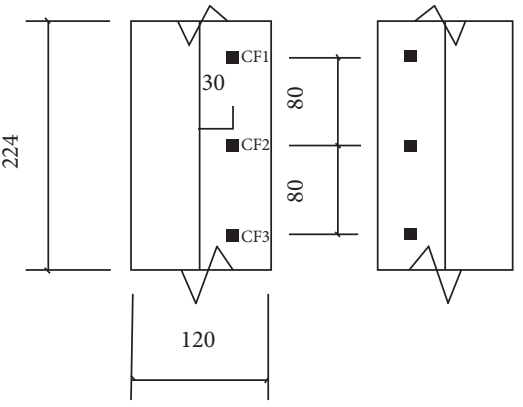

(c)

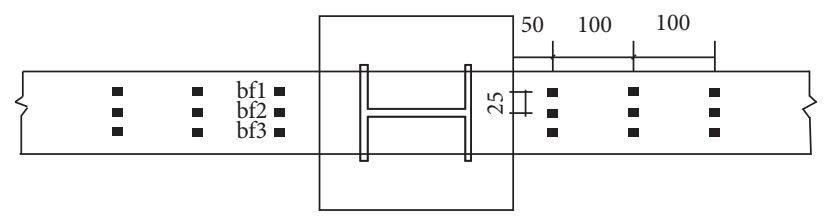

(d)

FiguRE 5: Strain gauges arrangement. (a) Column longitudinal and stirrup reinforcements. (b) Beam web/column web core area. (c) Column flanges. (d) Beam flanges.

envelope curve compared to SRC-1 and SRC-2, while after reaching ultimate capacity, SRC-2 showed a very flat curve and SRC- 1 and SRC-3 displayed an obvious descending curve. In particular, SRC-3 had flexural failure in beams and load bearing capacity dropped very quickly. This also indicated that proper axial compression ratio can improve composite columns-steel-beam joint's ultimate stability; therefore, mechanical performance of joint was degraded relatively after ultimate capacity was reached. SRC-4 showed an obviously greater cracking load than SRC-2, which verified that introducing $\mathrm{X}$-shaped reinforcing bars can slow down the appearance and development of cracks and therefore improve crack resistance of joints.

3.4. Ductility. The ratio of ultimate displacement to yield displacement was used for ductility assessment, with final failure set as the point when the load dropped to $85 \%$ of ultimate load capacity. Table 5 lists the displacement and ductility factor of SRC-1, SRC-2, and SRC-3. It can be seen that ductility coefficient for all three specimens decreased with axial compression ratio increasing.

\subsection{Strength and Stiffness Degradation}

$$
\eta=\frac{P_{j}^{i}}{P_{j}^{1}} .
$$

Equation (1) shows strength degradation coefficient $\eta$ [14]. $P_{j}^{i}$ represents peak load at load cycle of $i$ under displacement increment of $j$. Figure 14 shows strength degradation coefficient for three specimens under different axial compression ratios. It can be seen that the axial compression ratios did not influence strength degradation coefficient very much. Even after ultimate capacity $\eta$ still did not change much, while in ordinary concrete $\eta$ dropped quickly after reaching the ultimate capacity point. It indicates that SRC possess good damage resistance.

In this paper, stiffness $k$ was used to analyze the stiffness degradation trend during loading process. Stiffness $k$ is the ratio of the sum of the peak loads corresponding to each period to the sum of the peak displacements under the same load. As shown in Figure 15, under negative bending moment, three specimens 


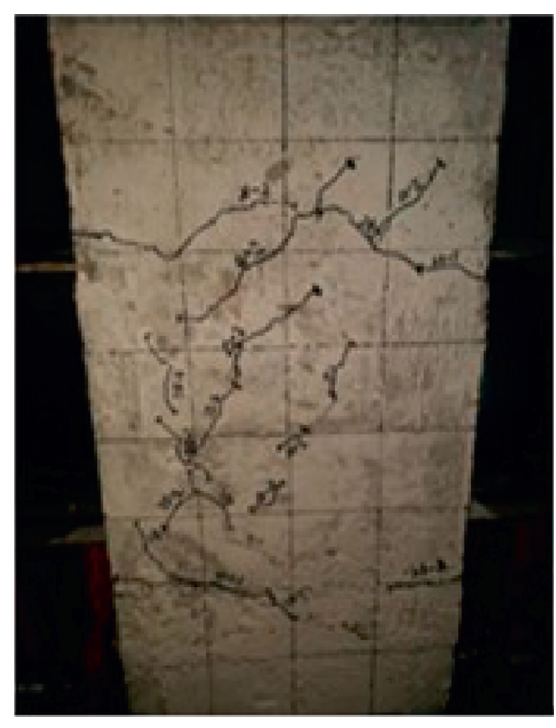

(a)

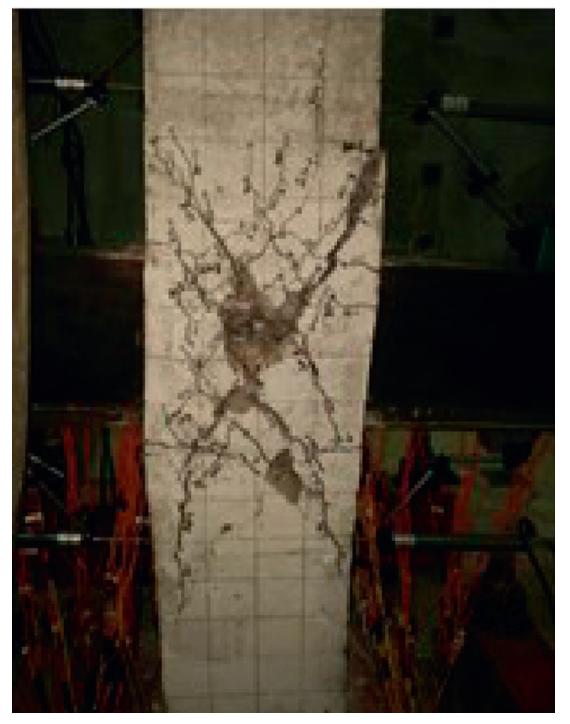

(c)

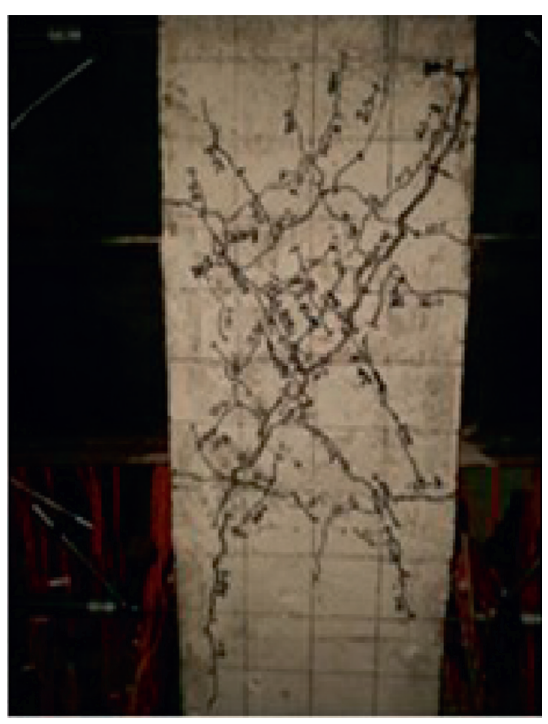

(b)

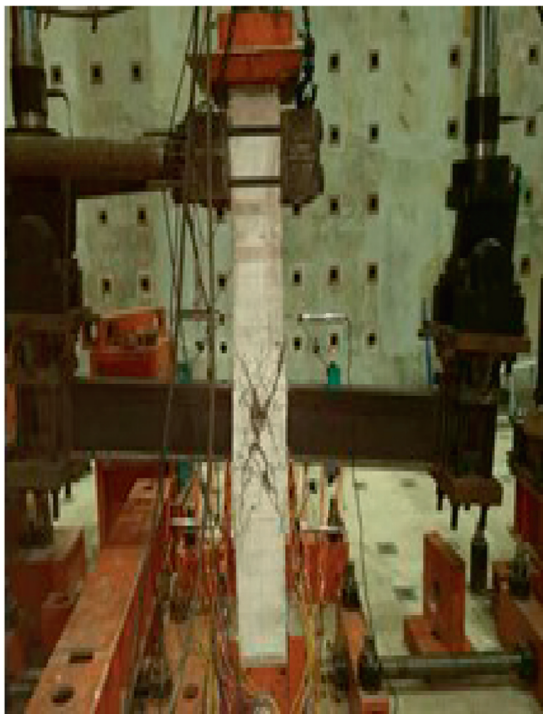

(d)

FIgURE 6: Failure modes of SRC-1. (a) Crack at yield capacity. (b) Crack development. (c) Final cracks. (d) Overall specimen at failure.

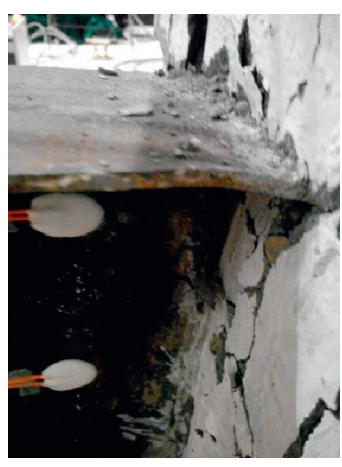

(a)

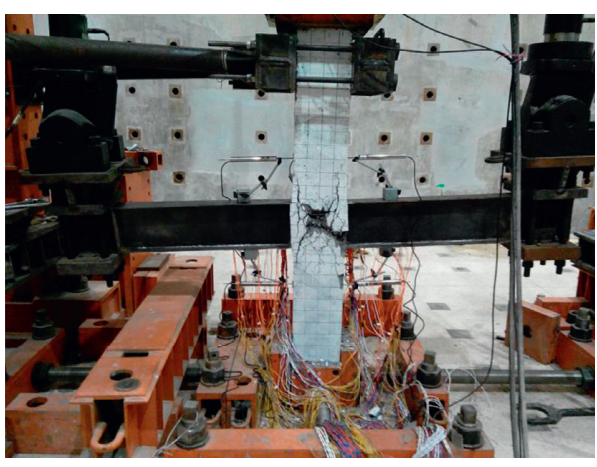

(b)

FIgURE 7: Failure modes of SRC-4. (a) Top flange buckling of beam. (b) Final failure mode. 


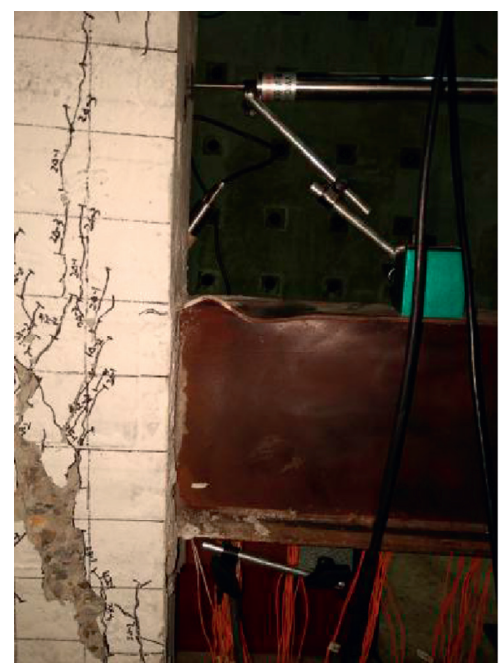

(a)

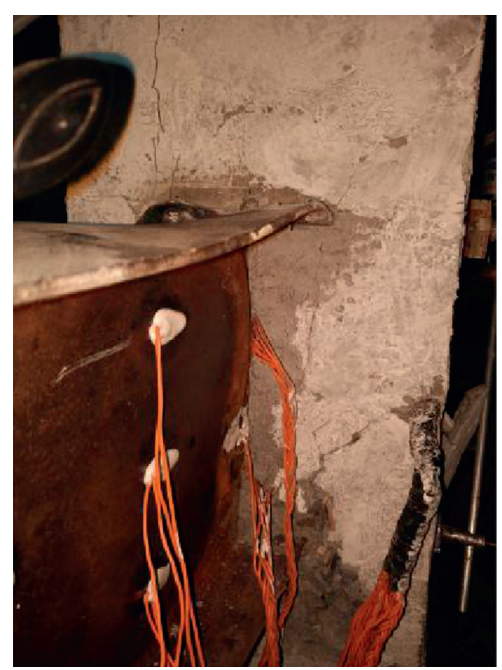

(b)

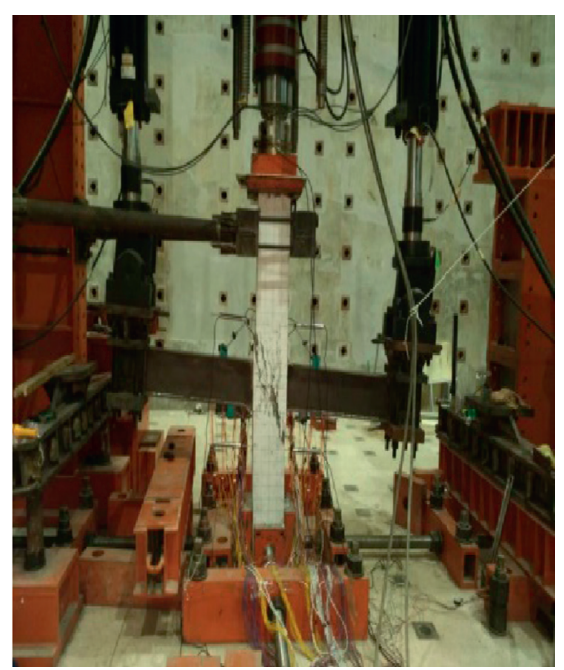

(c)

Figure 8: Failure modes of SRC-3. (a) Top flange buckling of beam. (b) Web buckling of beam. (c) Final failure mode.

TABLE 3: Failure modes of all specimens.

\begin{tabular}{|c|c|c|}
\hline $\begin{array}{l}\text { Sample } \\
\text { ID }\end{array}$ & Details of failure & Final failure mode \\
\hline SRC-1 & Severe concrete spalling and shear deformation in joint, buckling in beam bottom flange & Shear failure in joint \\
\hline SRC-2 & $\begin{array}{c}\text { Severe concrete spalling, later than that of SRC-1; shear deformation in joint, buckling in } \\
\text { both beam top and bottom flange }\end{array}$ & Shear failure in joint \\
\hline SRC-3 & $\begin{array}{c}\text { Severe concrete spalling, later than that of SRC-2; shear deformation in joint, buckling in } \\
\text { both beam flanges and web }\end{array}$ & $\begin{array}{l}\text { Shear failure in joint and beam } \\
\text { flexural failure }\end{array}$ \\
\hline SRC-4 & $\begin{array}{c}\text { Severe concrete spalling, later than that of SRC-2; shear deformation in joint, buckling in } \\
\text { both beam top and bottom flange }\end{array}$ & Shear failure in joint \\
\hline
\end{tabular}

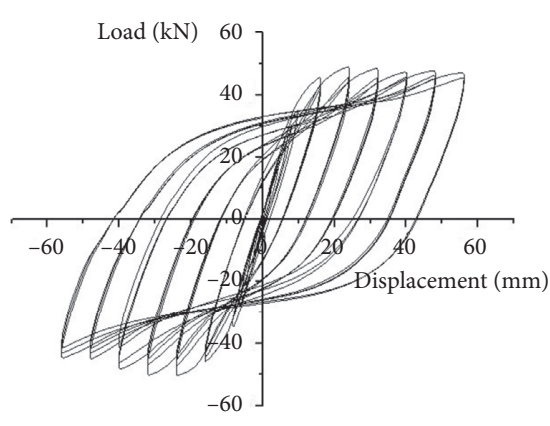

(a)

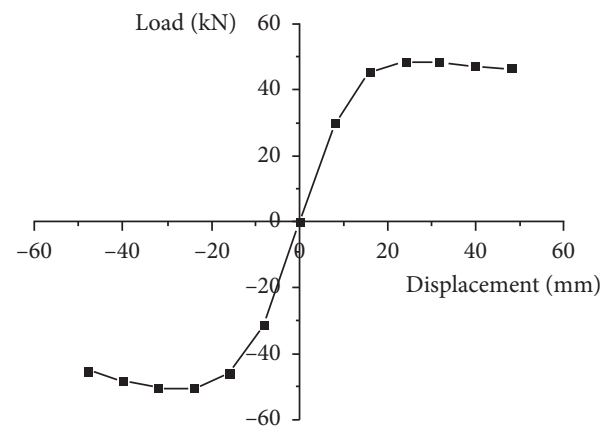

(b)

FIgURE 9: Hysteretic curve and envelope curve for SRC-1.

showed similar stiffness degradation trend, while under positive bending moment, SRC- 2 showed similar trend to SRC-3 and SRC-1 showed obviously higher curve than that of SRC-2 and SRC-3.

3.6. Energy Dissipation Ability. In this paper, equivalent viscous damping coefficient [15] was used to assess specimen's energy dissipation ability. As shown in Figure 16, equivalent viscous damping coefficient can be obtained through calculation in the following equation:

$$
h_{e}=\frac{1}{2 \pi} \cdot \frac{\left(S_{\mathrm{ABC}}+S_{\mathrm{ACF}}\right)}{\left(S_{\mathrm{OBD}}+S_{\mathrm{OFE}}\right)} .
$$

In this paper, only the equivalent viscous damping coefficients at ultimate capacity and at final failure point were analyzed for the three specimens and results are shown in Table 6. It can be seen from the table that the three specimens showed similar energy dissipation coefficients when the load reached ultimate capacity and all specimens showed increased coefficients at final failure points. It indicates that, 


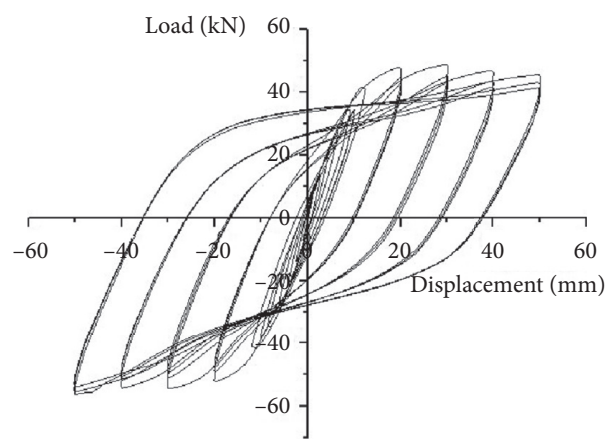

(a)

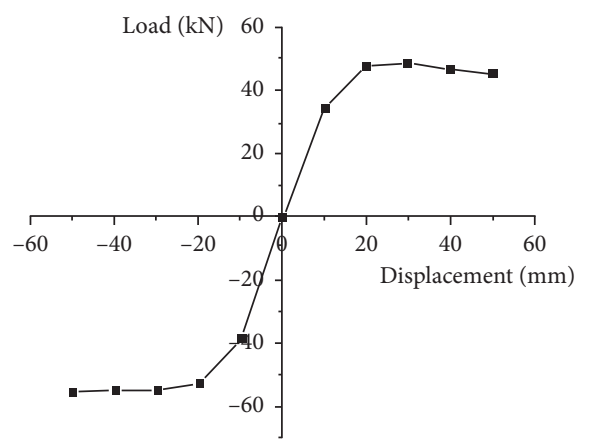

(b)

FIgURE 10: Hysteretic curve and envelope curve for SRC-2.

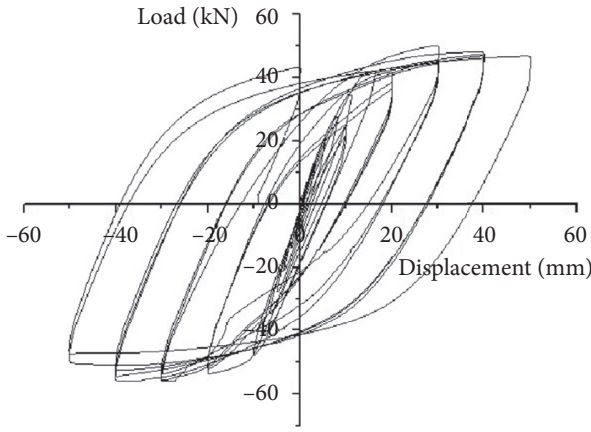

(a)

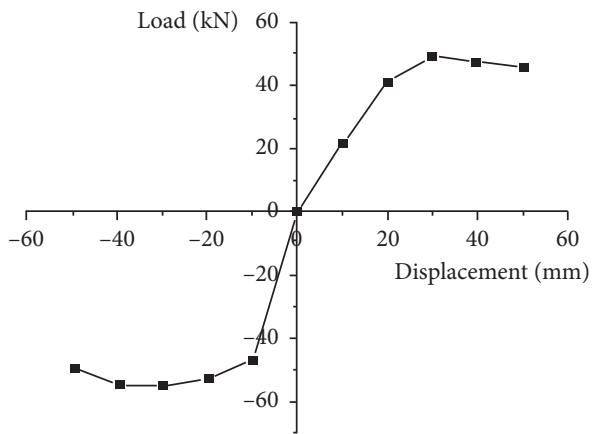

(b)

FIGURE 11: Hysteretic curve and envelope curve for SRC-3.

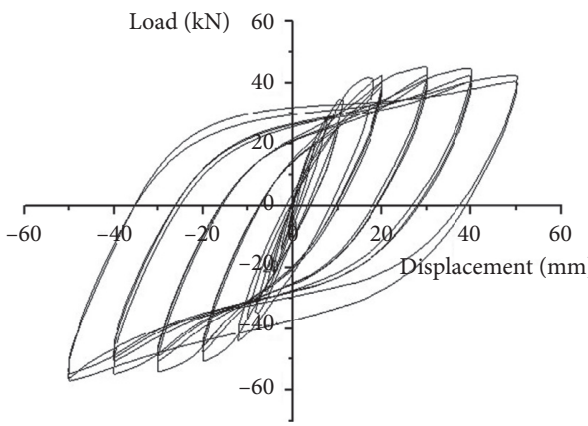

(a)

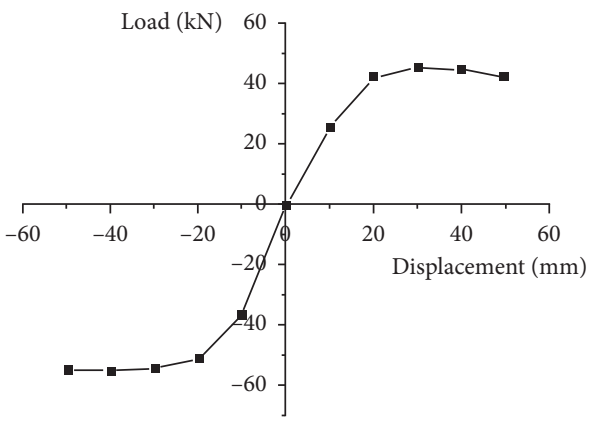

(b)

FIgURE 12: Hysteretic curve and envelope curve for SRC-4.

TABle 4: Characteristic load.

\begin{tabular}{lccc}
\hline Sample ID & Cracking load & Yielding load (kN) & Ultimate loading (kN) \\
\hline SRC-1 & $21 \mathrm{kN}$ in first cycle (positive displacement) & $34.74 /-34.76$ & $48.98 /-50.31$ \\
SRC-2 & $21 \mathrm{kN}$ in first cycle (negative displacement) & $41.72 /-41.77$ & $48.87 /-54.59$ \\
SRC-3 & $28 \mathrm{kN}$ in first cycle (positive displacement) & $41.75 /-41.80$ & $50.21 /-56.09$ \\
SRC-4 & $28 \mathrm{kN}$ in first cycle (positive displacement) & $41.32 /-41.46$ & $41.32 /-41.46$ \\
\hline
\end{tabular}




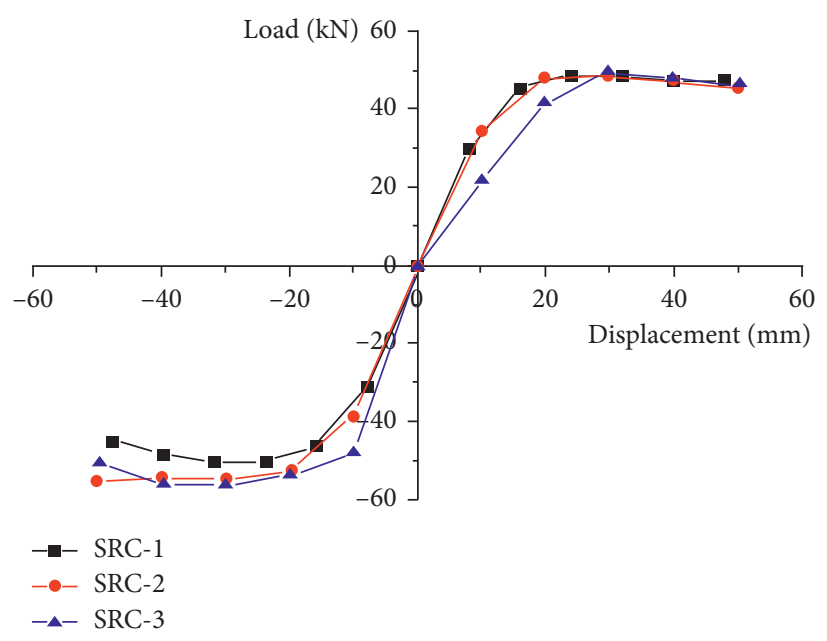

FIGURE 13: Envelope curves under varying axial compression rate.

Table 5: Displacement and ductility detail.

\begin{tabular}{|c|c|c|c|c|c|}
\hline \multirow{2}{*}{ Sample ID } & \multicolumn{2}{|c|}{ Displacement at yield (mm) } & \multicolumn{2}{|c|}{ Yielding load $(\mathrm{kN})(\mathrm{mm})$} & \multirow{2}{*}{$\begin{array}{c}\text { Ductility coefficient } \\
\text { Average }\end{array}$} \\
\hline & Positive & Negative & Positive & Negative & \\
\hline SRC-1 & 9.27 & 8.17 & 31.82 & 31.81 & 3.66 \\
\hline SRC-2 & 11.67 & 11.21 & 29.71 & 29.92 & 2.61 \\
\hline SRC-3 & 12.56 & 10.75 & 29.71 & 29.97 & 2.58 \\
\hline
\end{tabular}

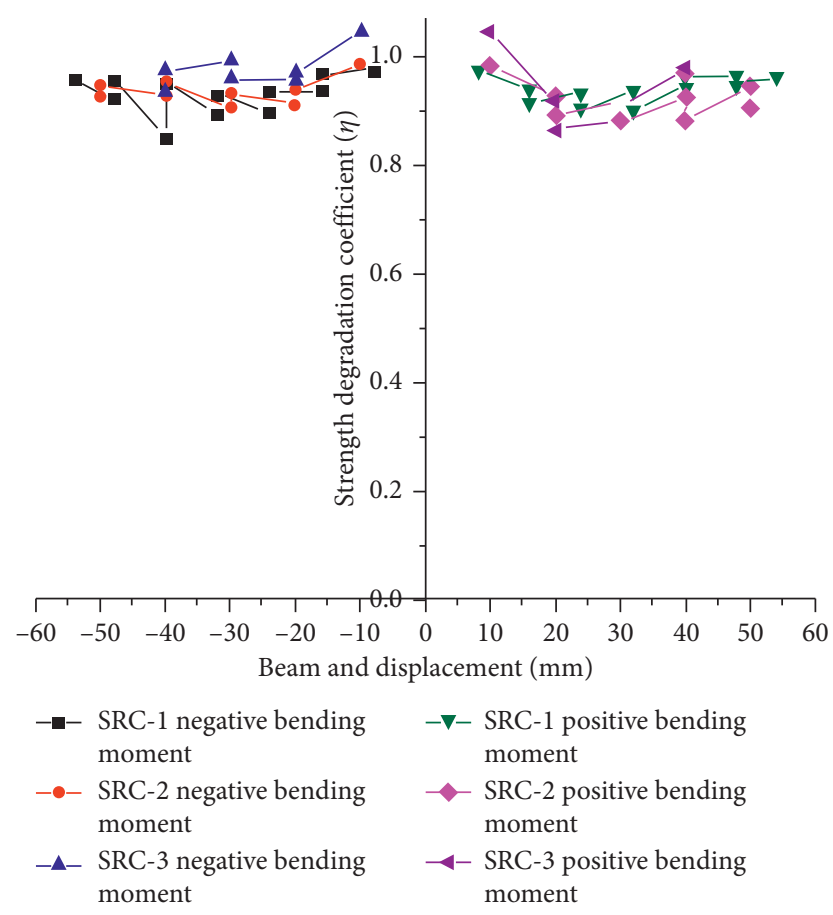

FIGURE 14: Strength degradation coefficient.

after ultimate capacity point, the load bearing capacity decreased very slowly and all joints showed good energy dissipation ability. The equivalent viscous damping coefficient of SRC-3 is higher than those of the other two specimens by 0.1 , which indicates that higher axial compression rate can help to improve energy dissipation ability. 


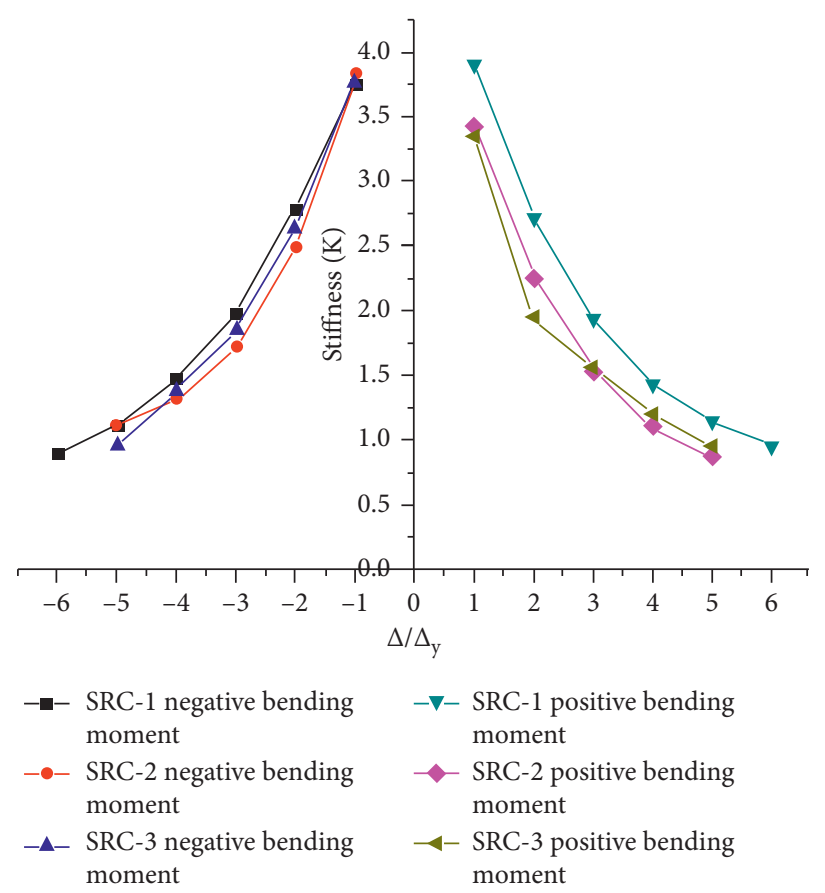

FIGURE 15: Stiffness degradation curves.

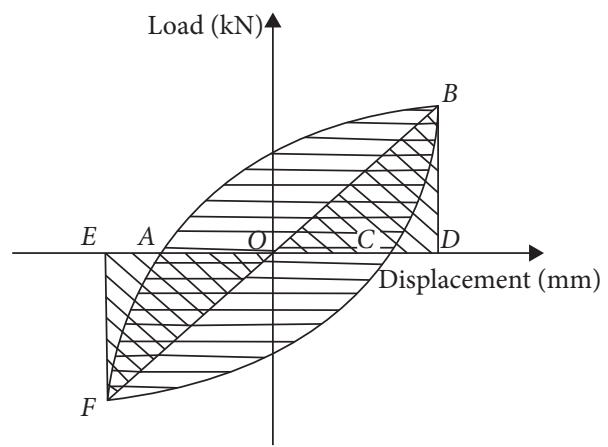

FIGURE 16: Calculation of $h_{e}$.

TABLE 6: Energy dissipation coefficients.

\begin{tabular}{lcccc}
\hline \multirow{2}{*}{ Sample ID } & \multicolumn{2}{c}{ Under ultimate capacity } & \multicolumn{2}{c}{ At failure } \\
& Area A & $h_{e}$ & Area A & 0.3 \\
\hline SRC-1 & 2300 & 0.23 & 4183 & \\
SRC-2 & 2257 & 0.24 & 4909 & 0.3 \\
SRC-3 & 2196 & 0.22 & 6091 & 0.4 \\
\hline
\end{tabular}

3.7. Shear Resistance Capacity. The two widely used practical codes on structural steel-concrete composite structure in China are JGJ 138-2001 [16] and YB 9082-2006 [17]. When seismic grade is not considered and only the impact from axial load is considered, the two standards provide shear resistance formula for SRC composite columns-steel-beam joints:

$$
\begin{aligned}
V= & \varnothing_{j} \eta_{j} 0.25+0.05 \frac{N}{f_{c} b_{c} h_{c}} f_{c} b_{j} h_{j} \\
& +f_{y v} \frac{A_{\mathrm{sv}}}{s} h_{0}-\alpha_{s}^{\prime}+0.58 f_{a} t_{w} h_{w},
\end{aligned}
$$


TABLE 7: Shear capacity calculated by equation (3).

\begin{tabular}{lccc}
\hline Sample ID & SRC-1 & SRC-2 & \\
\hline Axial compression ratio & 0.1 & 0.4 & SRC-3 \\
Axial compression & 140 & 560 & 0.7 \\
Shear capacity of concrete & 188.7 & 188.7 & 980 \\
Shear capacity of stirrups & 71.7 & 71.7 & 188.7 \\
Shear capacity of structural steel & 130.8 & 130.8 & 71.7 \\
Influence factor from axial force & 6.4 & 25.7 & 130.8 \\
Shear capacity calculated from equation (3) & 397.8 & 410.0 & 44.9 \\
\hline
\end{tabular}

TABLE 8: Shear capacity calculated by equation (4).

\begin{tabular}{lccc}
\hline Sample ID & SRC-1 & SRC-2 & SRC-3 \\
\hline Axial compression ratio & 0.1 & 0.4 & \\
Axial compression & 140 & 560 & 122.7 \\
Shear capacity of concrete & 122.7 & 71.7 & 180 \\
Shear capacity of stirrups & 71.7 & 130.8 & 71.7 \\
Shear capacity of structural steel & 130.8 & 51.3 & 130.8 \\
Influence factor from axial force & 12.8 & 376.6 & 89.8 \\
Shear capacity calculated from equation (4) & 338.1 & 415.1 \\
\hline
\end{tabular}

TABLE 9: Comparison between theoretical values and measured values.

\begin{tabular}{|c|c|c|c|}
\hline Sample ID & SRC-1 & SRC-2 & SRC-3 \\
\hline Testing result for shear capacity & 419.1 & 436.6 & 448.7 \\
\hline Calculated shear capacity from equation (3) & 397.8 & 410.0 & 436.3 \\
\hline Calculated shear capacity from equation (4) & 338.1 & 376.6 & 415.1 \\
\hline Test result/result from equation (3) & $105.4 \%$ & $104.7 \%$ & $102.9 \%$ \\
\hline Test result/result from equation (4) & $123.9 \%$ & $115.9 \%$ & $108.1 \%$ \\
\hline
\end{tabular}

$$
\begin{aligned}
V= & \delta_{j} f_{t} b_{j} h_{j}+\frac{f_{y v} A_{\mathrm{sv}}}{s} h_{j} \\
& +f_{\mathrm{ssv}} t_{w} h_{w}+0.1 N_{c}^{\mathrm{rc}} .
\end{aligned}
$$
force.

In equation (4), $0.1 N_{c}^{\mathrm{rc}}$ is the favorable influence of axial

Testing shear force is calculated through the following equation:

$$
V=\frac{M_{\mathrm{bl}}+M_{\mathrm{br}}}{h_{b 0}} \cdot \frac{1}{H} \cdot\left(H-\frac{h_{b 0} L}{L_{n}}\right),
$$

where $H$ is column height, $L$ is beam span, $L_{n}$ is clear span of beam, $h_{b 0}$ is effective height of beam, and $M_{\mathrm{bl}}$ and $M_{\mathrm{br}}$ are bending moments at left and right sides of beam. Tables 7 and 8 summarize shear capacity of three specimens, and Table 9 shows comparison between theoretical values and measured values.

It can be seen from Tables 7-9 that testing results for these three specimens are all higher than calculated results from two standards. Testing results increased with axial compression ratio, which indicates that it is a proper method to include the influence from axial compression force. Testing results are more close to results from equation (3), while equation (4) showed smaller shear capacity. Comparing Tables 7 and 8 , it can be seen that concrete shear capacity from equation (3) is much higher than that from equation (4), while the influence factor of axial force in equation (4) nearly doubles that from equation (3). Hence, based on the results from this paper, suggestions could be provided on modification of equation
(4), for example, increasing the calculated shear capacity of concrete and decreasing axial load.

\section{Finite Element Model (FEM)}

4.1. Model Setup. In order to better understand the behavior of SRC column-steel-beam structure and verify the accuracy of the experiment, ABAQUS was used to simulate the elements and loading process. With regard to concrete constitutive relationship, damage plasticity model was used to represent concrete plastic behavior. Concrete uniaxial compressive and tension stress-strain relationships suggested in GB50010-2010 [18] were employed. Concrete compressive and tensile strengths of $\mathrm{f}_{\mathrm{ck}}$ and $f_{t k}$ were from test results, which are shown in Table 1 . The von Mises yield criterion and related flow rules were adopted for steel simulation and yield strength used in the model was from test results, with yield strength of $297 \mathrm{MPa}$ for Q235 graded steel, 316 MPa for HPB300 graded steel, and $379 \mathrm{MPa}$ for HRB335 graded steel.

Concrete was simulated through reduced linear integrated unit C3D8R. Three-dimensional Truss unit T3D2 was used for reinforcement steel simulation. Three-dimensional shell unit S4R [19] was used for structural steel simulation. Meshed structure model is shown in Figure 17.

4.2. FEM Results Analysis. Figure 18 shows FEM results and also test results from SRC-3 on load-displacement hysteretic curves. Overall, the FEM results agree well with those from the test. Figure 19 shows the final failure mode of SRC-3. It can be seen clearly that shear deformation is severe, as well as 


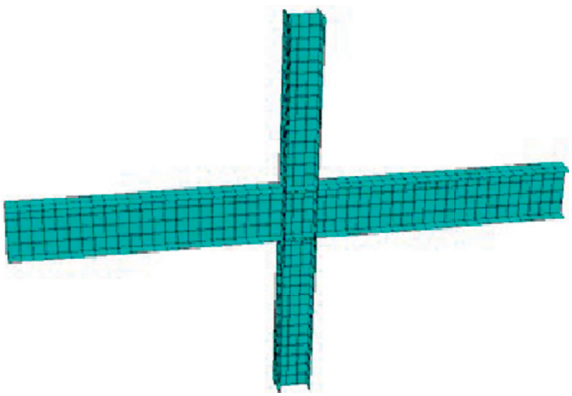

(a)

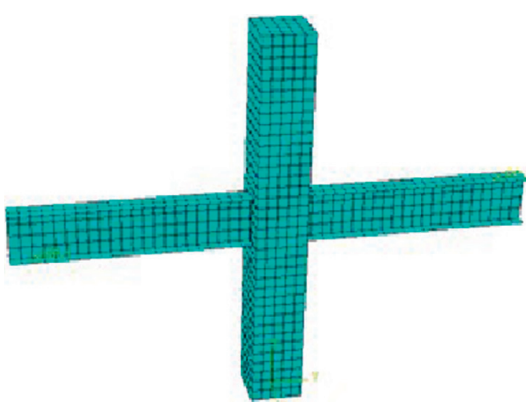

(b)

FIGURE 17: Meshed elements. (a) Joint from steel elements. (b) Joint from concrete column/steel beam.

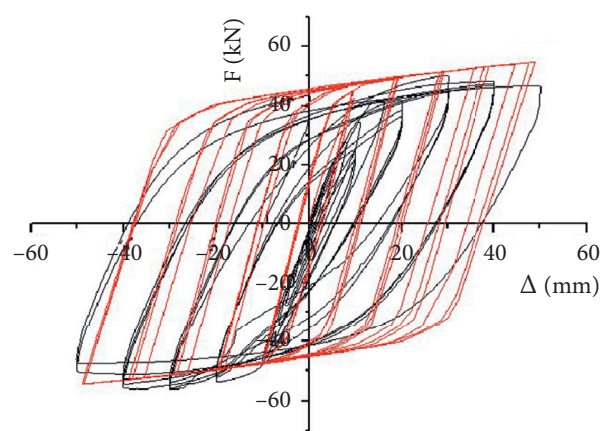

Test

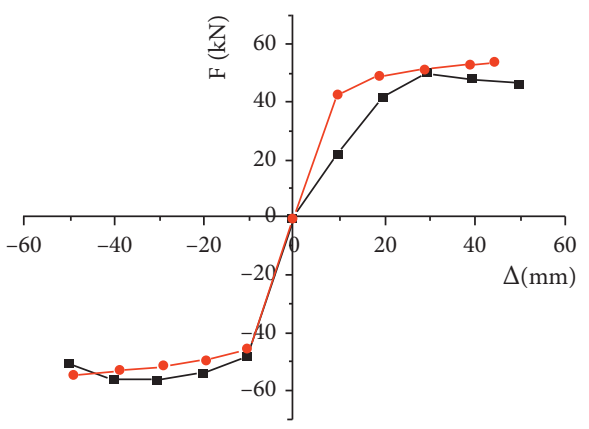

-1- Test

- - FEM

(a)

(b)

Figure 18: Hysteretic curve and envelope curve of SRC-3. (a) Hysteretic curve. (b) Envelope curve.

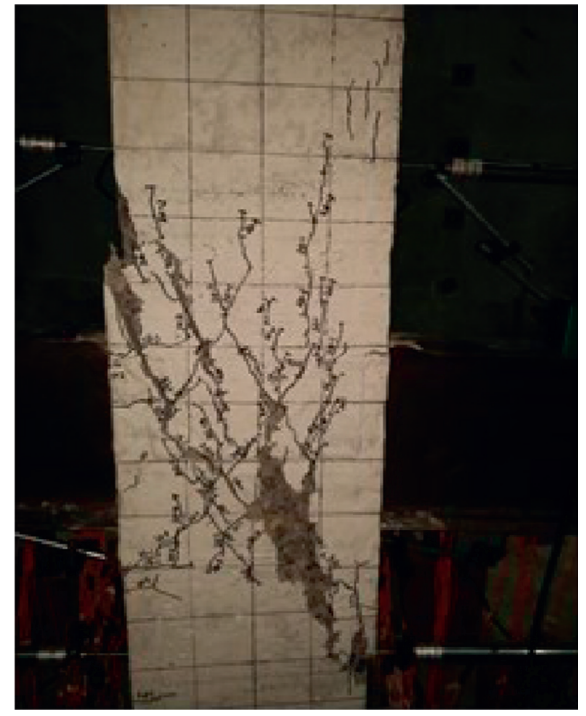

(a)

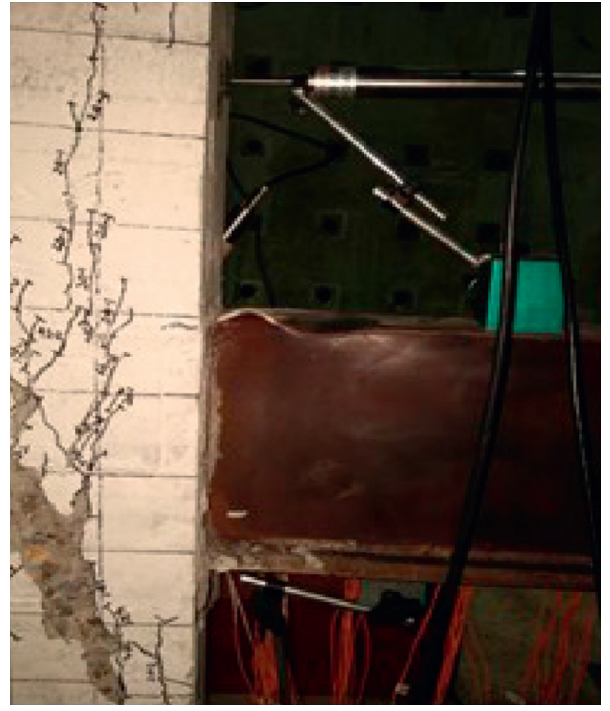

(b)

Figure 19: Continued. 


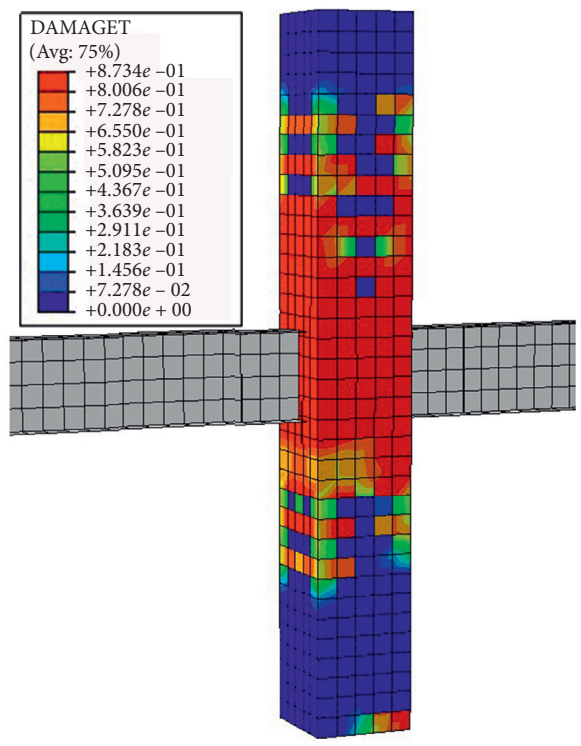

(c)

FIgURE 19: Failure mode of specimen SRC-3. (a) Final cracking. (b) Buckling in beam flange. (c) FEM result.

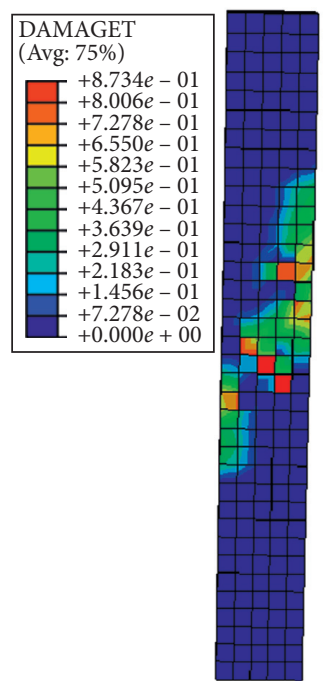

SRC-1

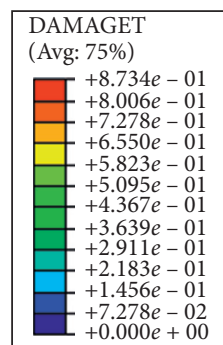

(a)

(b)

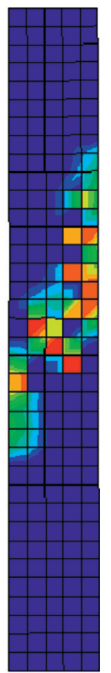

SRC-2

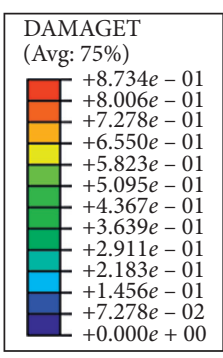

(c)

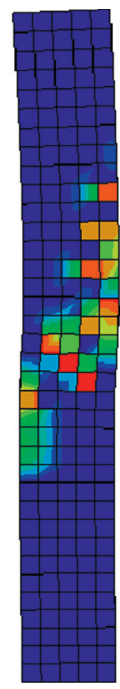

SRC-3
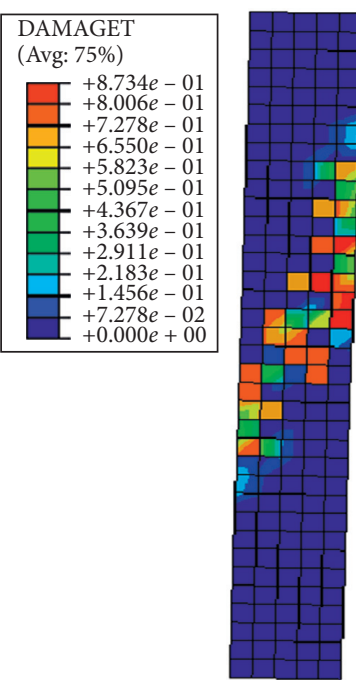

SRC-4

FIGURE 20: Initial cracking of concrete.

buckling and deformation in beam flanges and concrete spalling in concrete, which all agree with test phenomena. Figure 20 shows the damage contour on concrete tensile cracking from all four specimens and it can be seen from the figure that cracking load improves with increasing axial load, which indicates that increase of axial pressure ratio will improve anticracking ability and slow down crack development. SRC-4 shows obviously higher cracking load than SRC-2, which indicates that application of X-shaped rein- forcement joint area can not only affect crack locations but also improve concrete crack resistance.

4.3. Parametric Study. Through adjustment of concrete strength, stirrup ratio, stiffener thickness, and web thickness in FEM model, their influence on joint strength capacity is analyzed. The energy dissipation ability of specimen with axial compression ratio of 0.4 was greater than that of 
TABLE 10: FEM parameter analysis.

\begin{tabular}{|c|c|c|c|c|c|c|c|}
\hline $\begin{array}{l}\text { Sample } \\
\text { ID }\end{array}$ & $\begin{array}{l}\text { Concrete } \\
\text { strength }\end{array}$ & $\begin{array}{c}\text { Longitudinal bars in } \\
\text { column }\end{array}$ & $\begin{array}{l}\text { Stirrup bars in } \\
\text { column }\end{array}$ & $\begin{array}{l}\text { Stirrup bars } \\
\text { in joint }\end{array}$ & $\begin{array}{l}\text { Thickness of the } \\
\text { stiffener (mm) }\end{array}$ & $\begin{array}{l}\text { Web thickness } \\
(\mathrm{mm})\end{array}$ & $\begin{array}{c}\text { Axial pressure } \\
\text { ratio }\end{array}$ \\
\hline $\begin{array}{l}\text { SRC-5 } \\
\text { SRC }\end{array}$ & C30 & $4 \cdot 12$ & $.8 @ 100$ & .8@60 & $\mathrm{N} / \mathrm{A}$ & 8 & 0.4 \\
\hline SRC-6 & $\mathrm{C} 40$ & $4 \cdot 12$ & ·8@100 & ·8@60 & N/A & 8 & 0.4 \\
\hline SRC-7 & C50 & $4 \cdot 12$ & .8@100 & ·8@60 & N/A & 8 & 0.4 \\
\hline SRC-8 & $\mathrm{C} 30$ & $4 \cdot 12$ & ·8@100 & $\mathrm{N} / \mathrm{A}$ & N/A & 8 & 0.4 \\
\hline SRC-9 & C30 & $4 \cdot 12$ & .8@100 & .6@60 & $\mathrm{N} / \mathrm{A}$ & 8 & 0.4 \\
\hline SRC-10 & C30 & $4 \cdot 12$ & .8@100 & ·8@60 & N/A & 8 & 0.4 \\
\hline SRC-11 & C30 & $4 \cdot 12$ & ·8@100 & ·8@60 & $\mathrm{N} / \mathrm{A}$ & 8 & 0.4 \\
\hline SRC-12 & $\mathrm{C} 30$ & $4 \cdot 12$ & ·8@100 & ·8@60 & 4 & 8 & 0.4 \\
\hline SRC-13 & C30 & $4 \cdot 12$ & ·8@100 & ·8@60 & 8 & 8 & 0.4 \\
\hline SRC-14 & C30 & $4 \cdot 12$ & .8@100 & ·8@60 & N/A & 4 & 0.4 \\
\hline SRC-15 & C30 & $4 \cdot 12$ & .8@100 & ·8@60 & $\mathrm{N} / \mathrm{A}$ & 6 & 0.4 \\
\hline SRC-16 & $\mathrm{C} 30$ & $4 \cdot 12$ & ·8@100 & ·8@60 & N/A & 8 & 0.4 \\
\hline
\end{tabular}

TABle 11: Beam end loads and shear from FEM.

\begin{tabular}{|c|c|c|c|c|c|c|}
\hline Sample ID & Cracking load $(\mathrm{kN})$ & Yielding load $(\mathrm{kN})$ & Ultimate load $(\mathrm{kN})$ & Shear at cracking $(\mathrm{kN})$ & $\begin{array}{c}\text { Shear at } \\
\text { yielding }(\mathrm{kN})\end{array}$ & Ultimate shear $(\mathrm{kN})$ \\
\hline SRC-5 & 14.5 & 27.8 & 53.1 & 108.6 & 207.6 & 396.1 \\
\hline SRC-6 & 16.1 & 29.5 & 54.6 & 120.5 & 220.0 & 407.6 \\
\hline SRC-7 & 17.2 & 31.2 & 54.7 & 128.4 & 233.1 & 408.5 \\
\hline SRC-8 & 12.5 & 26.9 & 52.1 & 93.3 & 199.5 & 389.1 \\
\hline SRC-9 & 13.8 & 27.7 & 52.7 & 103.3 & 206.7 & 393.4 \\
\hline SRC-10 & 14.6 & 27.8 & 53.1 & 108.6 & 207.6 & 396.1 \\
\hline SRC-11 & 14.3 & 27.7 & 52.7 & 106.9 & 206.9 & 393.3 \\
\hline SRC-12 & 14.6 & 27.8 & 53.1 & 108.6 & 207.6 & 396.1 \\
\hline SRC-13 & 14.8 & 28.9 & 53.3 & 110.1 & 215.7 & 397.8 \\
\hline SRC-14 & 12.3 & 21.7 & 49.3 & 91.5 & 162.0 & 367.8 \\
\hline SRC-15 & 13.4 & 25.5 & 51.6 & 99.7 & 190.4 & 385.4 \\
\hline SRC-16 & 14.6 & 27.8 & 53.1 & 108.6 & 207.6 & 396.1 \\
\hline
\end{tabular}

specimens with 0.1 axial compression ratio, while the flexural failure of steel beams was caused by high axial compression ratio of 0.7 . The increase of axial compression ratio will increase the shear resistance capacity of joints, but it is only a small increase. Therefore, the axial compression ratio of 0.4 was selected for simulation.

In Table 10, concrete strengths for specimens SRC-5, SRC-6, and SRC-7 were C30, C40, and C50, respectively. There was no stirrup in SRC-8, while stirrup diameters of $6 \mathrm{~mm}$ and $8 \mathrm{~mm}$ were applied in SRC-9 and SRC-10, respectively. There was no stiffener in SRC-11, while stiffeners at thickness of $4 \mathrm{~mm}$ and $8 \mathrm{~mm}$ were applied in SRC12 and SRC-13, respectively. Specimens SRC-14, SRC-15, and SRC-16 are with web thickness of $4 \mathrm{~mm}, 6 \mathrm{~mm}$, and $8 \mathrm{~mm}$, respectively. One simulated parameter was verified for every three specimens. Other parameters were the same. Table 11 lists the load and shear resistance simulation results for three different stages of the specimen.

It can be seen from Table 11 that cracking shear force and yielding shear force increase with concrete strength increasing, while ultimate shear force was not affected very much. With increasing of stirrup diameter, cracking shear force is obviously improved, while addition of stiffener in joint area does not influence shear resistance very much. Compared with adding stiffener and stirrups, increasing web thickness can improve joint shear resistance more effectively.

Figure 21 shows that higher strength concrete makes bigger contribution to load sharing and this helps to lower the loading in structural steel web. With increase of stirrup in the joint area, this can improve shear resistance. With the increase of stiffener thickness, shear on stiffener increases and thus reduces the shear in steel web. At the same time, SRC-11 showed more severe steel buckling than the other two specimens, which indicates that adding stiffener in core area could reduce local buckling in steel flange and transfer shear to web uniformly and this finally reduces strain in web area. With web thickness increasing, the capacity and stability of joint can be obviously improved.

From the FEM results on parameter study, it can be concluded that those factors showed positive influence on improving joint shear resistance; in the order from the most obvious to the least obvious, they are web thickness, concrete strength, stirrup ratio, and stiffener thickness. Increasing web thickness is proved to be the most effective way for shear resistance improvement for SRC composite columns-steelbeam joints. 

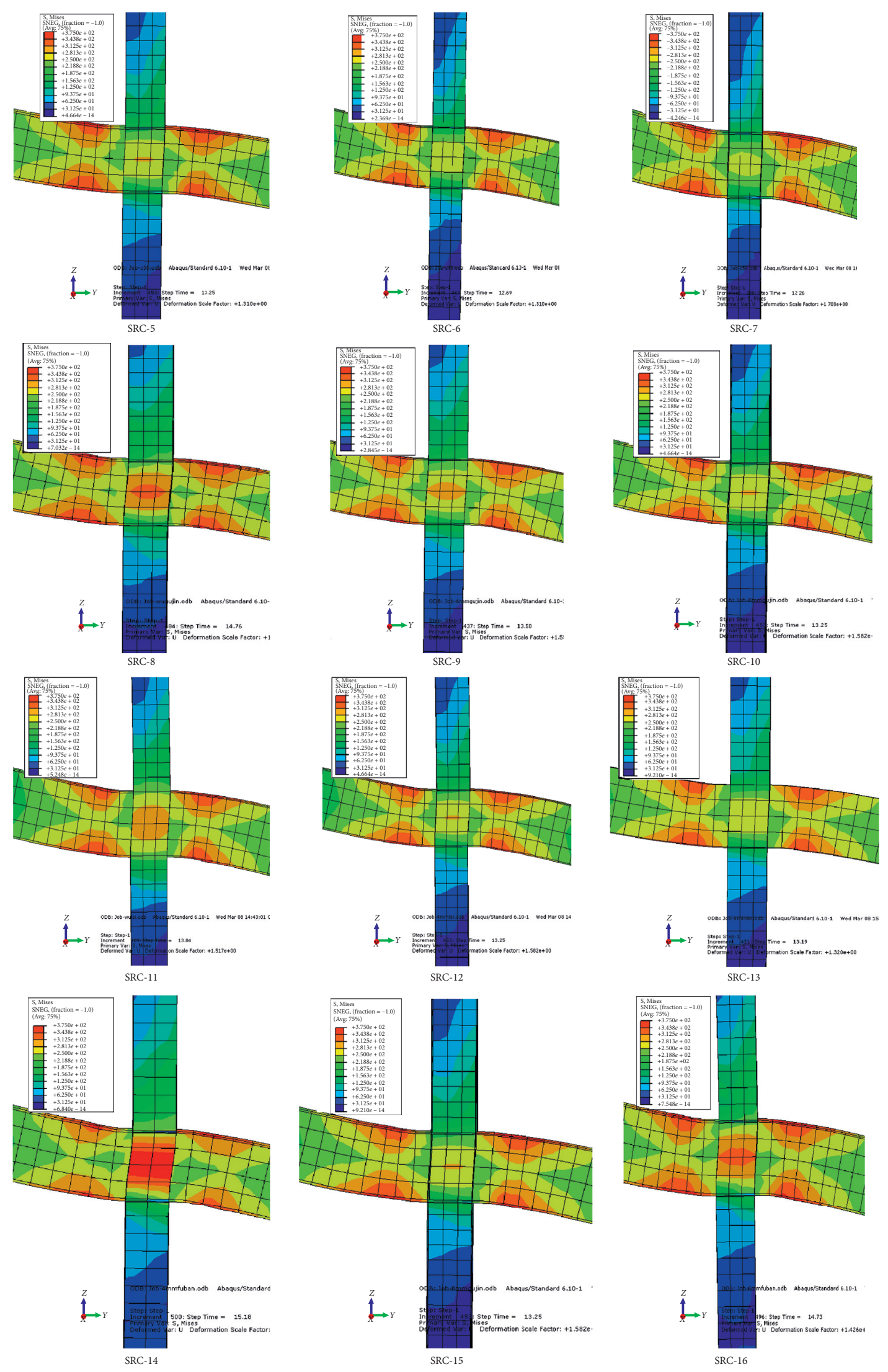

FigURE 21: Stress distribution of specimen in ultimate state. 


\section{Conclusion and Future Work Recommendation}

Experimental study was carried out on SRC composite columns-steel-beam joints under low-frequency cyclic loading. Results were verified by analysis result from FEM model using ABAQUS. Both experimental and FEM analysis results showed the following:

(1) Higher axial compression ratio can improve crack resistance; however, high axial force on SRC-3 caused flexural failure of beam and then finally led to reduction in overall joint stability and load capacity in structural steel.

(2) SRC-3 showed most full hysteretic curve among all specimens, which indicates good energy dissipation ability of SRC composite columns-steel-beam joints. With axial compression ratio increasing, ductility of joints decreased and strength degradation did not change very much, while stiffness decreased.

(3) Adding X-shaped reinforcement in joint area could slow down concrete cracking and improve crack resistance but does not affect other mechanical properties very obviously.

(4) Based on experimental results, suggestions could be made on modification of formula from YB9082-2006 [15] in that concrete shear capacity could be increased and positive influence from axial load could be reduced.

\section{Data Availability}

The relevant data in this paper can be obtained through relevant calculation or test.

\section{Conflicts of Interest}

The authors declare that there are no conflicts of interest regarding the publication of this paper.

\section{Acknowledgments}

This work was financially supported by the National Key R\&D Program of China (2016YFE0125600), Program for Innovative Research Team of Education Ministry of China (IRT_16R67), Thousand Talents Plan in Henan Province (ZYQR201912029), and the National Natural Science Foundation of China (no. 51408556).

\section{References}

[1] Y. Yang, Y. Xue, Y. Yu, and F. Gao, "Experimental study on seismic performance of partially precast steel reinforced concrete columns," Engineering Structures, vol. 175, pp. 63-75, 2018.

[2] J. M. Ding, S. Chao, X. Zhao, and H. L. Wu, "Critical issues of structural analysis for the Shanghai center project," Journal of Building Structures, vol. 31, no. 6, pp. 123-131, 2010, in Chinese.
[3] C. H. Chen, C. K. Wang, and H. Z. Su, "Experimental study on seismic behavior of full encased steel-concrete composite columns," Journal of Structural Engineering, vol. 140, no. 6, pp. 1-10, 2014.

[4] J. Y. Xue, Z. P. Chen, and H. T. Zhao, Performance, Design Method and Engineering Application of Steel Reinforced Concrete Special-Shaped Column Structure, China Architecture \& Building Press, Beijing, China, 2011, in Chinese.

[5] L. Chu, G. Li, D. Li, and J. Zhao, "Study on progressive collapse behavior of SRC column-steel beam hybrid frame based on pushdown analysis," Shock and Vibration, vol. 2017, pp. 1-12, 2017.

[6] C.-C. Chen, K.-T. Lin, and Y.-J. Chen, "Behavior and shear strength of steel shape reinforced concrete deep beams," Engineering Structures, vol. 175, pp. 425-435, 2018.

[7] W. P. Cheng, L. C. Wang, Y. P. Song, and J. Wang, "Seismic behaviour of beam-column joints of precast and partial steel reinforced concrete," Journal of Harbin Institute of Technology, vol. 22, no. 2, pp. 108-117, 2015.

[8] Z. P. Chen, J. J. Xu, J. Y. Xue, and N. Wang, "Deformation and energy-based seismic damage behavior of SRC specially shaped columns," China Civil Engineering Journal, vol. 48, no. 8, pp. 29-37, 2015, in Chinese.

[9] P. Xiang, Z. Deng, Y. Su, H. Wang, and Y. Wan, "Experimental investigation on joints between steel-reinforced concrete T-shaped column and reinforced concrete beam under bidirectional low-cyclic reversed loading," Advances in Structural Engineering, vol. 20, no. 3, pp. 446-460, 2016.

[10] L. S. Chu, D. D. Li, X. Ma, and J. Zhao, "Cyclic behaviour of concrete encased steel (CES) column-steel beam joints with concrete slabs," Steel and Composite Structures, vol. 29, no. 6, pp. 731-744, 2018.

[11] M.-X. Tao, J.-S. Fan, and J.-G. Nie, "Seismic behavior of steel reinforced concrete column-steel truss beam hybrid joints," Engineering Structures, vol. 56, pp. 1557-1569, 2013.

[12] S.-Y Seo, Y. Hyun-Do, and S.-H Kim, "Structural resistance of SRC column-steel beam joint developed for innovative," Construction of Buildings, Journal of Iron and Steel Research, vol. 18, no. A1, pp. 924-928, 2011.

[13] C. Standard, Specificating of Testing Methods for Earthquake Resistant Building (JGJ101-96), Architecture \& Building Press, Beijing, China, 1996.

[14] J. G. NIE, Y. Huang, and J. S. Fan, "Experimental study on load-bearing behavior of rectangular CFST frame considering composite action of floor slab," Journal of Building Structures, vol. 32, no. 3, pp. 99-108, 2011, in Chinese.

[15] R. Liu, Experimental Studies on the Seismic Behavior of CastIn-Situ Hollow Floor Slab-Column Strengthened Connections, Henan University of Technology, Zhengzhou, China, 2016, in Chinese.

[16] C. Standard, Technical Specification for Steel Reinforced Concrete Composite Structures (JGJ138-2001), Architecture \& Building Press, Beijing, China, 2001.

[17] C. Standard, Technical Specification of Steel-Reinforced Concrete Structures (YB9082-2006), Architecture \& Building Press, Beijing, China, 2006.

[18] C. Standard, Code for Design of Concrete structures (GB500102010), Architecture \& Building Press, Beijing, China, 2015.

[19] L. Fang, B. Zhang, G. F. JIN, K. W. LI, and Z. L. Wang, "Experimental study and finite element analysis on seismic behavior of steel reinforced concrete cross-shaped columns," Journal of Central South University(Science and Technology, vol. 46, no. 3, pp. 1027-1033, 2015, in Chinese. 